\title{
ПРИМЕНА ФИЛМА У НАСТАВИ ШПАНСКОГ КАО СТРАНОГ ЈЕЗИКА
}

У раду се анализира примена филма на часу шпанског као страног језика. С обзиром на то да филм поседује бројне предности које га чине подесним за дидактичку примену, његова употреба може допринети ефикаснијој настави. Аутентични материјал у виду аудио-визуелног формата пружа разноврстан језички инпут и контекстуализоване ситуације, на основу чега ученици развијају различите језичке вештине и компетенције. При том, присуство лудичког елемента додатно доприноси мотивацији ученика. За успешну примену филма на часу најважније је одабрати адекватан филмски материјал, организовати час и осмислити пропратне активности. Циљ рада је да укаже на ефикасност филма у настави и да нагласи потребу за посвећивањем више пажње примени филма у настави шпанског као страног језика у Србији.

Кључне речи: филм, шпански као страни језик, језичке вештине и компетенције, ефикасна настава

\section{Увод}

За разлику од досадашњих искустава у Србији, дидактичка примена филма у настави шпанског као страног језика је доста проучавана и широко распрострањена у свету. Захваљујући карактеристикама филма, дидактичка обрада филма обухвата широк спектар деловања, од развијања вештина слушања, до консолидације граматичке, прагматичке и социокултурне компетенције (Синг и Матур 2010: 7). Поред усавршавања знања

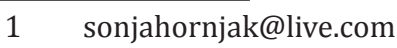


ученика, филм доприноси мотивацији и стварању пријатне атмосфере на часу, што је подједнако значајно за наставни процес. Иако овај иновативни приступ наизглед делује једноставно, рад са филмом подразумева одређене етапе. Најбитнији аспект представља одабир филмског материјала и организација часа уз пропратне активности. Значај филма у настави страног, односно шпанског као страног језика, препознају и кључни лингводидактички документи, Заједнички европски оквир за живе језике (ЗЕОЈ 2003) и Курикуларни план Инстиmута Сервантес (Plan Curricular del Instituto Cervantes 2002). Заједнички европски оквир за живе језике (ЗЕОЈ 2003: 76) чак уводи појам аудио-визуелне рецепције у оквиру рецептивних активности и стратегија, при чему гледање филмова убраја у активности аудио-визуелне рецепције (ЗЕОJ 2003: 76). Свакако да се филму могу наћи поједини недостаци, који се релативно лако могу надоместити адекватном употребом и избором филмског материјала.

С обзиром на то да у Србији до скоро овој теми није посвећено довољно пажње, предмет рада је анализа примене филма у настави шпанског као страног језика. Циљ рада је да укаже на ефиканост и предности примене филма у настави.

\section{Дидактичка перспектива филма у настави}

Иако се филм често сматрао забавним елементом у настави шпанског језика, он може да буде и едукативно средство (Васкес 2006: 36). Алварес Рохас и Тимон Бенитес (2010: 3940) сматрају да филм поседује одређене дидактичке функције, као што су информативна, мотивациона, лудичка, експресивна, истраживачка и металингвистичка. Поменуте функције пружају бројне могућности за рад, од представљања одређених садржаја, па све до подстицања ученика за самостално истраживање проучаваног садржаја. Спој поменутих функција чини филм пријемчивим средством за ученике, а уједно и за наставнике. 
Поред језичког материјала, филмом се представљају и репрезентативне друштвене и културолошке чињенице, које га чине подесним за приказивање различитих садржаја и употребу у настави шпанског као страног језика (ibidem 2010: 39). Филм се може применити на свим типовима часа шпанског језика. Могу се приказати различити садржаји и извести бројне активности у циљу вежбања потребних вештина и компетенција, било да се ради о понављању већ наученог градива или обради новог градива.

Гледањем филма мотивација ученика се повећава јер се код њих подстиче радозналост и ишчекивање тога шта ће се десити у наредним сценама (Стемплески и Томалин 2001: 1). При том, гледање филма изазива одређене емоције код гледалаца, односно ученика. Опште је познато да је знање трајније уколико су присутне емоције (Торе 2005: 22-23). Сплет когнитивних и емотивних процеса који настају у раду са филмом може утицати на остваривање ефикасније наставе.

\section{Предности филма у настави шпанског језика}

Карактеристике филма као аудио-визуелног формата, омогућавају бројне предности примене овог средства у настави. Спој звука и слике на првом месту, даје могућност ученицима да разумеју семантичку вредност речи, израза, говора тела и паралингвистичких елемената (Торо Ескудеро 2009: 3). Потом, та иста комбинација визуелног и звучног преноса поруке чини да сама порука буде постојанија (Торе 2005: 22-23), односно да је ученик боље запамти. Ученик побољшава и утврђује своје знање посматрајући директно значење оног што му се представља путем контекстуализованих слика (Канинг-Вилсон и Валас 2000: 2).

Филмови, као аутентичан материјал, чине део стварности хиспанског света (Лонерган 1984: 8). Представљају веома прикладан начин за увођење ситуација и језика из реалног живота на час (Бадок 1996: 20-22), при чему пружају разнолик језички импут (Стемплески и Томалин 2001: 1). Језик у филму, за 
разлику од видео материјала намењених странцима, јесте аутентичан, он доводи реалан живот у учионицу (Гомес Вилћес 1990: 248). Захваљујући визуелном елементу, сагледавају се елементи невербалне комуникације, који појачавају поруку или преносе афективну информацију (Вагнер 2010: 494). Филм приказује и паралингвистичке елементе, који се ретко помињу на часу, а чине саставни део комуникације (Брандимонте 2003: 870). Опште је познато да интеракција вербалних и невербалних компоненти доводи до комплетног разумевања поруке (Холек 1975 у: Вилис 1983: 30). Филм приказује ситуације које се тешко могу створити у учионици (Диас Перес 2001: 263). Посматрајући вербалне и невербалне елементе у комуникативном чину, ученици сагледавају комуникативну намеру говорника у одређеном контексту (Фонкубиерта Муриел 2006: 1148). Захваљујући динамичној, непосредној и приступачној комбинацији звука и слике, која се даје кроз контекст, ученици без проблема уочавају многобројне елементе који су саставни део комуникативног чина (Лонерган 1984: 4). За развијање комуникативне компетенције ученика веома је значајно да ученику буду представљене целокупне ситуације и предочени паралингвистички елементи и елементи невербалне комуникације. Уколико се ученик нађе у реалној језичкој ситуацији на шпанском говорном подручју, за остваривање комуникативног чина потребно је знање о свим овим елементима који чине комуникацију.

\section{Језичке вештине и компетенције које се развијају применом филма у настави шпанског језика}

Самора Пинел (2001: 32) истиче да су филмови једно од најбољих средстава за развијање свих рецептивних и продуктивних језичких вештина. Применом филма на часу вежбају се вештине попут усменог разумевања и изражавања, као и писмено разумевање и изражавање. Вештине усменог разумевања се директно вежбају гледањем филмског материјала. 
Усмено изражавање се додатно вежба потоњим разговором о теми филма, док се писмено изражавање усавршава писањем паралелних сценарија или интервјуа. Вештине читања могу се развијати кроз читање сценарија.

С обзиром на то да су на филму представљени културни садржаји попут особености одређене епохе, обичаја, гастрономије или моде (ibidem 2001: 32), ученици могу да усаврше и своју социокултурну компетенцију. Поред посматрања варијетета шпанског језика, ученик може да научи више и о ванјезичким аспектима (Брандимонте 2003: 877) и невербалној комуникацији као својственим елементима хиспанских култура. Као што Кастињеирас Рамос и Ереро Весино (1998: 817) наводе, филм приказује културу језика на делу, захваљујући чему ученик може да је прегледа у детаље.

Филм приказује бројне комуникативне ситуације за учење функционалних садржаја, као што је чин извињења или убеђивања некога у нешто (Добос 2010: 21). На филму су представљене и прагматичне карактеристике усменог текста, попут односа саговорника у одређеним комуникативним ситуацијама (Фонкубиерта Муриел 2006: 1146), које могу послужити за пример ученицима.

\section{Етапе у процесу примене филма}

У процесу примене филма постоји више етапа. Прва етапа представља припрему материјала пре часа, а друга етапа припрему материјала непосредно пред час (Диас Перес 2001: 270). Прва етапа подразумева припрему и осмишљавање обраде филма, док се друга етапа остварује у учионици (Ферес 1992: 104).

Први корак представља дефинисање дидактичких циљева од стране наставника, зависно од броја ученика, годишта, као и културног и образовног нивоа (Ферес 1992: 104). У првој фази се бира материјал, при чему треба имати у виду одређене критеријуме. Не би требало приказивати цео филм на часу, 
јер се не располаже довољном количином времена, а и пружа се превише информација (Кортес Буено 2005: 23). Решење је у приказивању сцена од неколико минута (Бустос Хисберт 1997: 95). Кортес Буено (2005: 23) сматра да нема потребе за анализом целог филма, већ је довољна једна сцена која анализира одређену тему. Сцене се могу поновити више пута. У зависности од дидактичког циља (Ферес 1992: 104), наставник бира садржаје које жели да представи, било да су садржаји културне или граматичке природе.

После одабира сцена, припремају се пропратне активности. Паблос Ортега (2004: 20) класификује активности на активности: пре гледања, током гледања и након гледања (antes del visionado, durante el visionado, después del visionado). Свака од ових активности би требало да поседује специфичне циљеве, од увођења ученика у контекст па све до интерпретације и дискусије о погледаном материјалу.

Уколико наставник из неког разлога није у могућности да припреми активности, може да користи већ припремљене активности из приручника специјализованих за примену филма у настави. На шпанском тржишту постоје бројни приручници, као што су: Vamos al cine, artículos y actividades para el trabajo con películas en la clase de español (Бембибре и Камара 2013), Español con películas (Дуерто, Гарсија-Вињо Санћес и др. 2010), De cine, fragmentos cinematográficos para el aula (Сантос Гаргаљо и Сантос Гаргаљо 2001) и други.

Захваљујући интернету постоје бројни блогови и веб-сајтови посебно намењени дидактичкој примени филма у настави шпанског језика, а којима се може приступити у сваком тренутку.

Треба имати у виду техничке услове с обзиром на то да може доћи до непредвиђених проблема око функционисања апарата (Самора Пинел 2001: 33). Да не би дошло до непредвиђених ситуација услед техничких проблема и да се не би одузимало много времена од часа, потребно је унапред проверити исправност опреме.

У раду са филмом могу се користити и помоћни материјали као што су транскрипција дијалога и информативни мате- 
ријали о филму (Аменос Понс 1996: 52). Транскрипција сцена пружа ученику писмене контекстуализоване примере нових језичких фраза (Аменос Понс 1996: 52), а може и да помогне ученику уколико нешто није разумео.

\section{Могући недостаци}

Филму као дидактичком средству поједини аутори налазе и неке недостатке. Међутим, могући недостаци се могу спречити одговарајућом и правилном применом и адекватним одабиром материјала (Бустос Хисберт 1997: 95). Дужина трајања филма може бити потенцијална мана, која се лако избегава кроз приказивање краћих филмских сцена.

Филму се замера да изазива пасиван став ученика, с обзиром на то да ученици активирају поједине функције мозга развијајући само вештине слушања (Ескудеро Ројо 1997: 36). Међутим, при раду са филмом, ученик је активан и укључен у наставу јер гледајући филм развија критичко мишљење (Мартинес-Саланова Санћес 2002: 56). Филм утиче не само на побољшање рецептивних, већ и продуктивних вештина, јер обезбеђује стимулус за потоњу причу (Биедма Торесиљас и Торес Санћес 1994: 538). Филм оставља простора за индивидуално тумачење поруке филма (Аменос Понс 1996: 51), при чему је ученик активнији него обично. Филм не пружа директну интеракцију са публиком. Међутим, може се остварити повратна информација са ученицима у виду активности читања, интеркултурног и лингвистичког разумевања (Васкес 2006: 38). Интеракција наставника и групе успешно надомешћује овај недостатак (Аменос Понс 1996: 51).

Поједини аутори замерају да је филм фикција, међутим режисер је члан те говорне заједнице и свесно или несвесно преноси лингвистичке и културне елементе (Биедма Торесиљас и Торес Санћес 1994: 541). Језик у филму може бити компликован и тежак за разумевање, али ово није проблем ако се избор филма прилагоди нивоу знања ученика (Корпас Вињалс 2000: 786). 
Рад са филмом није једноставан, јер захтева од наставника доста времена за припрему часа, више од једног гледања и осмишљавање задатака (ibidem 2000: 786). Међутим, уколико наставник није у могућности да сам осмисли час и активности, увек може да користи већ припремљене активности из приручника или са блогова и сајтова који су специјализовани за рад са филмом на часу шпанског језика.

Иако се филму као дидактичком средству могу приписати одређени мањи недостаци, сваки од њих је могуће избећи адекватном употребом. Као што наводи Торо Ескудеро (2009: $20)$, једино ограничење у примени филма на часу се налази у креативности наставника.

\section{Закључак}

Захваљујући савременим технологијама, ученици су навикли на свакодневну аудио-визуелну комуникацију. Управо због тога, филм је средство блиско ученицима, а може се применити у дидактичке сврхе.

Јединствени спој звучног и визуелног канала преноса поруке, информативног и лудичког аспекта, когнитивних и емотивних елемената, чини да подобност филма пронађе своје место у курикулумима шпанског као страног језика. Применом филма ученици вежбају све језичке вештине и унапређују како лингвистичку, тако и прагматичку и социокултурну компетенцију. При том развијају и мотивацију, а ствара се и пожељна динамика на часу и пријатна атмосфера за рад и учење (Лонерган 1984: 5), што само по себи има вредност у дидактичком смислу. Посебно се истиче могућност примене филма у раду са великим групама (Бартоломе 1999: 18). Поред групне наставе, примена филма на часу шпанског језика погодна је и за индивидуалну наставу (ibidem 17). Као што Добос (2010: 19) наводи, филмови воде ученике ка другим земљама и културама и приближавају им свет без потребе да се физички крећу ка другим земљама. 
Рад са филмом представља вишедимензионалан процес у којем је потребно добро организовати час и све пропратне активности. Не треба заборавити да, упркос присуству технологије, наставник има кључну улогу у спровођењу и реализацији часа са филмом.

Потребно је пратити савремене дидактичке токове, искуства и иновације у свету, и на основу њих неопходно је указати на растућу праксу примене филма у настави шпанског као страног језика. У ту сврху филм постаје моћно средство на часу којем је потребно посветити више пажње, као и организовању семинара и обука за наставнике за рад са филмом.

\section{ЛИТЕРАТУРА}

Алварес Рохас и Тимон Бенитес 2010: Álvarez Rojas, M., Timón Benítez, L. M. (2010). El cine en la escuela como recurso en el área de educación visual: aspectos educativos y actividades para su desarrollo en la ESO. Sevilla: Wanceulen editorial.

Аменос Понс 1996: Amenós Pons, J. (1996). Cine, lengua y cultura, Frecuencia L, revista de didáctica Español como Lengua Extranjera, 3, 50-52.

Бадок 1996: Badock, В. (1996). Using Films in the English Class. Phoenix: Prentice Hall.

Бартоломе 1999: Bartolomé, A. (1999). Nuevas tecnologías en el aula, Guía de supervivencia. Barcelona: Grao.

Бембибре и Камара 2013: Bembibre, C., Cámara, N. (2013). Vamos al cine, artículos y actividades para el trabajo con películas en la clase de español (nivel intermedio/avanzado B1/C2). Madrid: Edinumen.

Биедма Торесиљас и Торес Санћес 1994: Biedma Torrecillas, A., Torres Sánchez, M. A. (1994). El estímulo cinematográfico: desarrollo de destrezas comunicativas y valor cultural, in: J. Sánchez Lobato, I. Santos Gargallo (eds.), Problemas y métodos en la enseñanza del español como lengua extranjera. Actas del IV Congreso Internacional de ASELE, Madrid: Universidad Complutense de Madrid, 537-552.

Бустос Хисберт 1997: Bustos Gisbert, J. М. (1997, septiembre). Aplicaciones del vídeo a la enseñanza de español como lengua extranjera, in: I. Alonso Belmonte (ed.), Nuevas tecnologías aplicadas a la enseñan- 
za de E/LE. Segunda etapa Carabela, 42,Monográfico, Madrid: SGEL, 93-105.

Брандимонте 2003: Brandimonte, G. (2003). El soporte audiovisual en la clase de E/LE: el cine y la televisión, in: H. Perdiguero, A. Álvarez (eds.), Medios de comunicación y enseñanza del español como lengua extranjera. Actas del XIV Congreso Internacional de ASELE, Burgos: Universidad de Burgos, 870-881.

Вагнер 2010: Wagner, E. (2010). The Effect in the Use of Video Texts on ESL Listening Test-tasker Performance, Language Testing, SAGE, 493-513. Online: http://ltj.sagepub.com/content/27/4/493 (1.12.2014)

Васкес 2006: Vázquez, L. (2006). El cine como vehículo de cultura en la clase de ELE, Frecuencia L, revista de didáctica Español como Lengua Extranjera, 32, 36-43.

Вилис 1983: Willis, J. (1983). The Role of the Visual Element in Spoken Discourse: Implications for the Exploitation of Video in the EFL Classroom, in: J. McGovern (ed.), Video Applications in English Language Teaching, Oxford: British Council and Pergamon Press, 29-42.

Гомес Вилћес 1990: Gómez Vílches, J. (1990). La explotación de películas en el aula de español para extranjeros, in: S. Peydra Montesó, A. Garrido Moraga (eds.), ¿Qué español enseñar? Norma y variación lingüísticas en la enseñanza del español a extranjeros. Actas del II Congreso Internacional de ASELE, Málaga: Universidad de Málaga, 247-253.

Tope 2005: Torre, S. de la (2005). Aprendizaje integrado y cine formativo, in: S. de la Torre, M. A. Pujol, N. Rajadell (eds.), El cine, un entorno educativo, Madrid: Narcea, 13-36.

Диас Перес 2001: Díaz Pérez, J. C. (2001). Del cine y los medios tecnológicos en la enseñanza de español/LE, in: A. M. Gimeno Sanz (ed.), Actas del XII Congreso Internacional de ASELE, Valencia: Universidad Politécnica de Valencia, 263-272.

Добос 2010: Dobos, E. (2010). El cine, una herramienta eficaz en la enseñanza de la comunicación intercultural, in: T. Bánki (ed.), El cine en la enseñanza de E/LE. XI Congreso AHPE, Ministerio de educación, Budapest: Edition Mediterranica, 19-25.

Дуерто, Гарсија-Вињо Санћес и др. 2010: Duerto, R., Garciá-Viñó Sánchez, M. et al. (2010). Español con películas. Madrid: Edinumen.

Ескудеро Pojo 1997: Escudero Royo, A. (1997). Televisión y educación, in: S. de la Torre (ed.), Cine formativo. Una estrategia innovadora en la enseñanza, Barcelona: Octaedro, 35-41.

Заједнички европски оквир за живе језике: учење, настава, оцјењивање 
2003: Zajednički evropski okvir za žive jezike: učenje, nastava, ocjenjivanje. Council of Europe. (prevod, 2003). Podgorica: Ministarstvo prosvjete i nauke.

Канинг-Вилсон и Валас 2000: Canning-Wilson, C., Wallace, J. (2000). Practical Aspects of Using Video in the Foreign Language Classroom, The Internet TESL Journal, vol. VI, 11. Online: http://iteslj.org/Articles/Canning-Video.2001html (1.10.2013)

Кастињеирас Рамос и Ереро Весино 1998: Castiñeiras Ramos, A., Herrero Vecino, C. (1998). Más allá de las imágenes: el cine como recurso en las clases de español, in: T. Jiménez Juliá, M. C. Losada Aldrey, J. Márquéz Caneda (eds.), Español como lengua extranjera: enfoque comunicativo y gramática. Actas del IX Congreso Internacional de ASELE, Santiago de Compostela: Universidad de Santiago de Compostela, 817-824.

Корпас Вињалс 2000: Corpas Viñals, J. (2000). La utilización del vídeo en el aula de ELE. El componente cultural, in: M. A. Martín Zorraquino, C. Díez Pelegrín (eds.), ¿Qué español enseñar? Norma y variación lingüísticas en la enseñanza del español a extranjeros. Actas del XI Congreso Internacional de ASELE, Zaragoza: Universidad de Zaragoza, 785-791.

Кортес Буенос 2005: Cortés Bueno, E. (2005, mayo). Introducción al cine: otra forma de aprender español, Frecuencia L, revista de didáctica, español lengua extranjera, 28, 23-28.

Лонерган 1984: Lonergan, J. (1984). Video in Language Teaching. Cambridge: Cambridge University Press.

Мартинес-Саланова Санћес 2002: Martínez-Salanova Sánchez, E. (2002). Aprender con el cine, aprender de película. Una visión didáctica para aprender e investigar con el cine. Huelva: Grupo Comunicar Ediciones.

Паблос Ортега 2004: Pablos Ortega, C. de (2004, novembar). La construcción del componente cultural en la clase de E/LE: propuesta didáctica a través del cine de Pedro Almodóvar, Frecuencia L, 27, 18-21.

Plan Curricular del Instituto Cervantes (2002). Centro Virtual Cervantes. Online: http://cvc.cervantes.es/ensenanza/biblioteca_ele/plan_ curricular (11.05.2015)

Самора Пинел 2001: Zamora Pinel, F. (2001). Aplicación del cine a la clase de E/LE, Cuadernos Cervantes de la lengua española, 33, 32-36.

Сантос Гаргаљо и Сантос Гаргаљо 2001: Santos Gargallo, I., Santos Gargallo, A. (2001). De cine, fragmentos cinematográficos para el aula. Madrid: SGEL. 
Синг и Матур 2010: Singh, V., Mathur, I. (2010). El cine como instrumento didáctico en las aulas de ELE en un país de Bollywood, MarcoELE. Revista de didáctica ELE, 11,1-18. Online: http://marcoele.com/descargas/11/singhmathur_cine_en_india.pdf (21.10.2014)

Стемплески и Томалин 2001: Stempleski, S., Tomalin, B. (2001). Film. Oxford: Oxford University Press.

Торо Ескудеро 2009: Toro Escudero, J. I. (2009). Enseñanza del español a través del cine hispano: marco teórico y ejemplos prácticos, in: II Jornadas de formación de profesores de ELE: estrategías de enseñanza y aprendizaje del español en China. Suplementos MarcoELE, 8, 1-68. Online: http://marcoele.com/descargas/china/ji.toro_cinehispano. pdf (12.10.2014)

Фepec 1992: Ferrés, J. (1992). Vídeo y educación. Barcelona: Ediciones Paidós.

Фонкубиерта Муриел 2006: Foncubierta Muriel, J. М. (2006). Ejercicios para el desarrollo de la comprensión audiovisual, la expresión y la interacción oral mediante el uso de las nuevas tecnologías, in: E. Balmaseda Maestu (ed.), Las destrezas orales en la enseñanza del español L2-LE. Actas del XVII Congreso Internacional de ASELE, Logroño: Universidad de Logroño, 1145-1149.

\section{Sonja Hornjak}

\section{THE FILM APPLICATION IN TEACHING SPANISH AS A FOREIGN LANGUAGE}

\section{Summary}

In this paper, we analyzed the film application in the class of Spanish as a foreign language. Due to the fact that film has many advantages which make it adequate for didactic application, it can contribute to a more efficient teaching process. An authentical material in audiovisual format provides various language input and contextualized situations, on whose basis students develop different linguistic skills and competences. Thereby, the presence of a ludic element additionally contributes to student's motivation. For a successful film application in the class, the most important thing is to select adequate film material, to organize class and 
make the accompanying activities. The purpose of the paper is to point out at the efficiency of film in teaching, as well as to point out at the need for paying more attention to film application in teaching Spanish as a foreign language in Serbia.

Key words: film, Spanish as a foreign language, linguistic skills and competences, efficient teaching process

Примљено 20. септембра 2016. године Прихваћено за објављивање 16. новембра 2016. године 